IRA-International Journal of Education \& Multidisciplinary Studies

ISSN 2455-2526; Vol.04, Issue 01 (2016)

Institute of Research Advances

http://research-advances.org/index.php/IJEMS

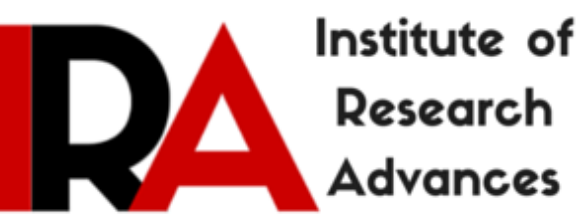

\title{
The Pedagogy of Blended Learning: A Brief Review
}

\author{
Dr. Agha Nuruzzaman
}

Assistant Professor, Department of Business Administration

AMU Centre Kishanganj, Bihar, India.

DOI: http://dx.doi.org/10.21013/jems.v4.n1.p14

\section{How to cite this paper:}

Nuruzzaman, A. (2016). The Pedagogy of Blended Learning: A Brief Review. IRA

International Journal of Education and Multidisciplinary Studies (ISSN 2455-2526), 4(1). doi:http://dx.doi.org/10.21013/jems.v4.n1.p14

(C) Institute of Research Advances

\section{(cc) BY-NC}

This works is licensed under a Creative Commons Attribution-Non Commercial 4.0 International License subject to proper citation to the publication source of the work.

Disclaimer: The scholarly papers as reviewed and published by the Institute of Research Advances (IRA) are the views and opinions of their respective authors and are not the views or opinions of the IRA. The IRA disclaims of any harm or loss caused due to the published content to any party. 


\section{ABSTRACT}

Pedagogy has long been seen in terms of an art, a science or a craft. The journey of pedagogy has seen many ups and downs, like it was a practice of luxury in the past, made for the privileged ones; then it also became a tool of oppression in some places. Today, it is again going through a churning phase- marked with numerous experiments and novelties. The present paper is an effort to review the methods of teaching and training students focusing on a few upcoming pedagogical methods. Blended learning environment is based on the assumption that the inherent benefits of face-to-face interaction maybe enhanced by using on-line methods. It promotes a student-centred learning and encourages increased student interaction. In addition, by providing students with more control over their learning, blended learning can also help in improving a critical thinking. It gives students more autonomy to choose their learning practices. The teacher may not be an omniscient and omnipresent figure any more but his/ her optimal presence is altered for the better as well. The teacher needs to be more creative with his/her learning now. But as freedom always comes with more responsibility, Blended Learning also needs a very careful assimilation of the various methods.
\end{abstract}

Key words: pedagogy, methodology, blended learning, challenges

\title{
1. Introduction
}

\section{Pedagogy}

Pedagogy is the method and practice of teaching, especially as an academic subject or theoritical concept.

Pedagogy is the discipline that deals with the theory and practice of education; it thus concerns the study and practice of the best way to teach. Its aims range from the general to the narrower specifics of vocational educational.

Watkins and Mortimere (1999) define it as 'any conscious activity by one person designed to enhance the learning of another' (p3). Leach and Moon (1999) expand further by describing a Pedagogical Setting as 'the practice that a teacher, together with a particular group of learners creates, enacts and experiences' (p267)

Some examples of pedagogy are simulation, case study, assignment, modelling, video, role play, exercise, tutorial, audio, lecture, project, power point, quiz etc.

\section{Blended Learning}

The terms "blended," "hybrid," "technology-mediated instruction," "web-enhanced instruction," and "mixed-mode instruction" are often used interchangeably in current research literature.

Blended learning designates the range of possibilities presented by combining Internet and digital media with established classroom forms that require the physical co-presence of teacher and students.

Friesen and Norm (2012) defined that Blended learning is a formal education program in which a student learns at least in part through delivery of content and instruction via digital and online media with some element of student control over time, place, path, or pace.

Blended learning has been in use since the popular advent of the Internet and the World Wide Web in the late 1990s. The present, blended learning has been understood as a combination of face-to-face and technology mediated instructional forms and practices. At the same time, the phrases "face-toface" and "technological mediation" themselves may generally benefit from further definition and contextualization. The major advantage that blended learning offers is scale, where one instructor can only teach many people. 
The Sloan Consortium provides more flexibility for the ratio which is delivered online and proposes that blended courses are those in which 30 to 79 percent of the content is delivered in an online format, while the remaining course content delivered in the more traditional classroom setting (Allen, Seaman and Garrett, 2007).

Blended learning methodologies accommodate the student's active life schedule while still providing the social connections that are necessary for clear communication to exist, ultimately supporting retention and success (Hijazi et al., 2006).

History: The precise origin of the term "blended learning" is uncertain. However, one of the first occurrences that has been identified is its use in a 1999 news release from EPIC Learning, an Atlanta based computer skill certification and software training business

\section{Review of Literature}

Boyle et al (2003) found that the blend represents a mixture of traditional and novel elements, with the novel elements more marked in the online developments. Results demonstrated marked improvements in pass rates. Evaluation of the students' use of the new environment indicated a generally positive evaluation of the main elements of the blend and widespread use of the new online features.

Cottrell \& Robinson (2003) in their research were interested in the possibility of using blended approaches to reduce faculty time, re-focus student time and using blended learning as a way to admit more students to a given academic program. Students reported preferring the blended learning approach and classroom time was reduced.

Cox et al (2004) evaluates the educational effectiveness of online chats, considering the roles of course design, group dynamics and facilitation style. Results found that these three factors strongly influenced the successful use of this medium and student participation.

Dowling et al. (2003) in their study investigated the association between the learning outcomes of students and two teaching modules: traditional face-to-face and hybrid flexible delivery. Results indicated that the hybrid flexible delivery model is more positively associated with students' final marks and improved learning outcomes.

Dziuban et al. (2004) describes the benefits of combined face-to-face instruction and online learning, including the potential to increase learning outcomes, lowering attrition rates, and high satisfaction among the majority of faculty and students.

Frazee (2003) explored whether the relevance-enhancing strategy of modifying the title of online discussion prompts to make an explicit connection to a particular course assignment increases student participation and satisfaction with online discussions. Students in both the control and treatment groups found the online discussions to be relevant and satisfying, with declining participation over time. There was no significant difference between the control and treatment groups in terms of perceived relevance, satisfaction, self-efficacy, or participation in the online discussions.

Garrison \& Kanuta (2004) commented that blended learning represents an opportunity to support deep learning. The authors build on earlier work using community of inquiry model to support why institutions should invest in transforming learning. The paper outlines what colleges and universities need to do to move forward blended learning.

Graff (2003) indicated that students with intuitive cognitive styles report a lower sense of community than students with an intermediate or analytic style. Few differences were found with respect to gender and sense of community in a blended learning environment. 
Kerres et al. (2003) explore a didactical framework which includes three components: content, communication and constructive. The 3C model can be applied to any learning environment but in blended learning it is critical to design how much time should be spent on each component. The role of various learning theories and media theories and uses are explored as background for approaching didactical design. The blend should consider the learning goals, the situational issues, target group and institutional issues to create an optimal blended learning environment.

King \& Hildreth (2001) investigated the effectiveness of a freshman-level Internet-based biology course. The authors compared student performance and attitudes from an Internet-based biology course to that of a traditional biology course. There were no significant differences between students' test scores in the Internet-based and traditional courses. The authors concluded that the Internet-based course was worthwhile, one-on-one contact between the instructor and students was higher in the Internet-based course, and that the Internet-based course provided multiple sources of information for students.

MacDonald \& McAteer (2003) investigates generic tutoring strategies and describes factors influencing the use of media in blended learning environments. Results established that many of the principles underlying effective strategies apply in both distance and campus-based universities.

O'Toole \& Absalom (2003) found that those students who attended lecture and read web materials performed better on the quiz than did those students who only attended lecture or only used the web.

Parkinson et al. (2003) found that the students in the traditional courses expressed satisfaction in all themes: classroom climate, learning needs, learner efficacy, interactions, and appropriate format for the content. Students in the distance format felt a lack of class community and belonging, and were often confused or uncertain about course material, but persevered because they felt it the only feasible way to attain their educational goals.

Priluck (2004) examined the effect of two technologically different teaching methods of marketing course on student responses. A traditional, face-to-face- method of teaching was compared to a webassisted method of instruction. Results indicated that students in the traditional course were more satisfied with their learning experience. These students felt that the course helped them develop their skills in critical thinking, team building, and social interaction.

Reasons et al. (2005) designed a business course which could be delivered in three formats: face-toface, blended and fully online. Three hypotheses state that interaction with course website, final grades and course participation will be significantly different in all three formats. The courses were taught in teacher education and health services using similar pedagogical techniques. Results demonstrated that the internet (online) course outperformed the other types of courses.

Riffell \& Sibley (2004) examines the effect of a hybrid course format (Part online, part face-to-face) on student attendance. A traditional lecture course was compared to a hybrid introductory college science course. Results indicated that completion rates of online homework were significantly greater than attendance rates to lectures. Also, this difference increased with higher class rank. Therefore, it is postulated that hybrid courses may increase student attendance, particularly for upperclassmen.

Rovai \& Jordan (2004) examines the effect of traditional classroom, blended, and fully online course formats on sense of community. The research hypothesis was that sense of community would be strongest in the blended course due to the greater range of opportunities for student interaction with peers and professors. Results indicated that blended courses did, in fact, produce a greater sense of community than either traditional or fully online course. This finding is attributed to the fact that blended learning courses allow professors to think less about delivering instruction and instead focus on producing learning and reaching out to students. 
Schweizer et al. (2003) examined how groups of learners work together in blended learning and elearning environments. Three pure e-learning courses were compared to one blended learning course were participants formed learning teams who met at three points in time. All participants received joint learning material, in order to build shared knowledge, and individualized information to build unshared knowledge. Variables analyzed include students' extent of online activity, the groups' task performance, and coherence of the groups' discourse. Results indicated that achievement in a particular group does not depend solely on the mode of communication used in the course.

While some instructors still argue that a traditional classroom is the richest and most feasible teaching medium, blended instruction allows ample opportunities for building social relationships between the teacher and students. Blended courses offer the convenience and flexibility of entire online courses without the loss of faculty or student interaction (Sitter, Carter, C., Mahan, Massello, \& Carter, T., 2009, p. 42).

\section{Objective of the study}

To understand the pedagogy of blended learning

An overview of blended learning

On the basis of review, try to find out the advantages and challenges of blended learning.

\section{Research Methodology}

The present study is descriptive in nature, based on the secondary data. The paper focuses especially on the past studies and on the basis of that, tries to fulfil the proposed objectives.

\section{Models of Blended Learning}

According to Friesen (2012), Blended Learning can generally be classified into six models:

$>$ Face to face driver - where the teacher drives the instruction and augments with digital tools.

$>$ Rotation - students cycle through a schedule of independent online study and face-to-face classroom time.

$>$ Flex - Most of the curriculum is delivered via a digital platform and teachers are available for face-to-face consultation and support.

$>$ Labs - The entire curriculum is delivered via a digital platform but in a consistent physical location. Students usually take traditional classes in this model as well.

$>$ Self-Blend - Students choose to augment their traditional learning with online course work.

$>$ Online Driver - All curriculum and teaching is delivered via a digital platform and face-to-face meetings are scheduled or made available if necessary.

\section{Advantage}

Blended instruction may enable schools to maximize classroom space and/or reduce the number of overcrowded classrooms.

Blended instruction allows multiple classes to utilize one physical space, like computer labs (Gould, 2003). 
Improvements in classroom utilization have the potential to reduce direct instructional costs by 25 50 percent (Dziuban, Hartman and Moskal, 2004).

$>$ The peak hours of classes can be controlled by Hybrid courses and maximizing the scant resources by increasing flexibility in scheduling (Gould, 2003, p. 55).

$>$ Schools can also reap institutional savings. The cost of paper and photocopying is easily reduced in it. As all course documents, syllabi, lecture notes, assignment sheets and other hard copy handouts, are accessible to the students on the course web site (Gould, 2003, p. 55).

Bowen (2006) suggests that technology can be a tool to "free" instructors from using class time to "cover" content in the classroom.

The physical classroom should be utilized in meaningful activities that benefit from face-to-face interaction between classmates and the instructor.

If a detailed ethical case study is made available online for students to read and research, class sessions can be utilised to present theoretical arguments by students for both sides of the issue. It could be in the form of group discussion, large or small, or even debate.

$>$ The expansion of blended course delivery has significantly helped parking problems on campuses (Hijazi et al., 2006; Dziuban, Hartman \& Moskal, 2004).

$>$ Proponents of blended learning argue that incorporating the "asynchronous Internet communication technology" into higher education courses serves to "facilitate a simultaneous independent and collaborative learning experience" (Garrison \& Kanuka, 2004),

Use of new communication technologies improve not only access to learning but it also energises students' attitudes towards learning (Alexander, 2010).

Communication between lecturers and part-time students is also found to have improved. Students were able to evaluate their understanding of course material via the use of "computer-based qualitative and quantitative assessment modules" in a better way, as study by Alexander and McKenzie (1998) show.

Students with special talent or interest can use educational technology to advance their skills or exceed grade restrictions. Some online institutions connect students with instructors via web conference technology to form a digital classroom involving latest technology.

\section{Challenges}

Blended learning has a strong dependence on the technical resources - these tools need to be reliable, easy to use, and up to date in order to be used (Garrison \& Kanuka, 2004).

Additionally, IT literacy can serve as a significant barrier for students attempting to get access to the course materials, making the availability of high quality technical support paramount (Alexander, 2010).

Adult learners returning to school may have questionable technical skills. In fact, about $50 \%$ of adults experience computer-related phobia (Saade \& Kira, 2009).

Unpleasant side effects associated with technology may include strong, negative emotional states before or during the interaction. 
Frustration, confusion, anger, anxiety and similar emotional states associated with the interaction can adversely affect productivity, learning, social relationships and overall well-being (Saade \& Kira, 2009, pg. 179).

Faculty need to be aware that not all students have the same degree of technological expertise and ensure that supports are in place to assist those who are novice e-learners.

The students' anxiety should be taken care of.

Support may be acquired for many facets of e-learning tasks such as posting discussion threads, uploading course materials, taking quizzes, accessing wikis, blogging and working together in virtual groups.

Participating in a blended or hybrid course requires students to be self-motivated learners with effective time management skills. Students are responsible for successful interactional classroom environment.

$>$ A change from a lecture-oriented class to student-centred active learning can constitute a radical change for some students, especially older students unaccustomed to taking responsibility for their own learning.

Faculty resistant to online course delivery can often see the benefits of blended course delivery; however moving a traditional course to a blended format requires careful consideration of educational objectives and methodologies.

Garnham \& Kaleta (2002) noted that in order to teach a successful hybrid course, the instructor must invest a significant amount of time and effort into the redesign of the class.

It has been observed that the use of lecture recording technologies can result in students falling behind on the material - in a study performed across four different universities, it was found that only half of the students watched the lecture videos on a regular basis, and nearly $40 \%$ of students watched several weeks' worth of videos in one sitting (Gosper et al, 2008)

\section{Conclusion}

Blended learning has been defined in different ways by the authors, and still new definitions are evolving. It is beneficial to the institutions, like minimizing costs of class room space, parking area, faculty etc. Students are kings when it comes to blended learning for the liberty it endows on them. They can attend the classes according to their desired place and convenient time. They are released of clock bound classes. Studies can be taken as part of the game now as they are much comfortable with their apps and androids. Books and libraries are obsolete things for them.

But studies also reveal a much shadowed aspect of blended learning. Participating in a blended or hybrid course requires students to be self-motivated and sincere. But this is a high expectation from the present generation. It is found that majority of the students are unable to show proper concentration and punctual participation in this method of learning. It has created a new generation which is debt-ridden; debt of catching up with timely work load! Majority of faculty is still counting on the face-to-face teaching.

But change is the spirit of life. It is time we accept blended learning. 


\section{References}

1. Alexander, (2010), "Flexible Learning in Higher Education", In: Editors-in-Chief: Penelope Peterson, Eva Baker and Barry McGaw, Editor(s)-in-Chief, International Encyclopedia of Education (Third Edition), Elsevier, Oxford, Pages 441-447, ISBN 9780080448947, http://dx.doi.org/10.1016/B978-0-08-044894-7.00868-X.

2. Alexander, S., \& McKenzie, J. (1998), “ An Evaluation of Information Technology Projects for University Learning", Canberra, Australia: Committee for University Teaching and Staff Development and the Department of Employment, Education, Training and Youth Affairs.

3. Allen, I. E., Seaman, J. and Garrett, J. (2007), "Blending In: The Extent and Promise of Blended Education in the United States", Needham, MA: The Sloan Consortium, March 2007. Retrieved on 27-21-2015 from http://www.sloanc.org/publications /surveyb/pdf/ Blending_In.pdf.

4. Bowen, A., (2006), "Grounded Theory and Sensitizing Concepts", International Journal of Qualitative Methods 5 (3) September 2006, pp. 1-9, http://www.ualberta.ca/ ijqm/

5. Boyle, T., Bradley, C., Chalk, P., Jones, R., \& Pickard, P. (2003, October), “Using blended learning to improve student success rates in learning to program", Journal of Educational Media, 28(2-3), 165-178.

6. Corcoran, G. (2009), "Blended learning lead institute", Proceedings of the Australian Vocational Education and Training Research Association. Retrieved on 24-01-2015 from http://www.avetra. org.au/papers-2009/papers/94.00.pdf.

7. Cottrell, D.M. \& Robinson, R.A. (2003), " Blended learning in an accounting course", The Quarterly Review of Distance Education, 4(3), 261-269.

8. Cox, G., Carr, T., \& Hall, M. (2004), "Evaluating the use of synchronous communication in two blended courses", Journal of Computer Assisted Learning, 20, 183-193.

9. Dowling, C., Godfrey, J.M., \& Gyles, N. (2003, December), "Do hybrid flexible delivery teaching methods improve accounting students' learning outcomes?", Accounting Education, 12(4), 373-391.

10. Dziuban, C., Hartman, J., \& Moskal, P. (2004, March 30), "Blended learning", ECAR Research Bulletin. Available online at http://www.educause.edu/ecar/

11. Frazee, R.V. (2003), "Using relevance to facilitate online participation in a hybrid course", Educause Quarterly, No. 4, 67-69.

12. Friesen (2012), "Report: Defining Blended Learning"

13. Friesen, Norm (2012), "Report:Defining Blended Learning"

14. Garnham, C., \& Kaleta, R. (2002), "Introduction to hybrid courses. Teaching with Technology Today, 8(6). Retrieved February 8, 2015, from http://www.uwsa.edu/tt/articles/garnham.htm

15. Garrison, D. R., \& Kanuka, H. (2004), "Blended learning: Uncovering its transformative potential in higher education", The Internet and Higher Education, 7, 95-105.

16. Garrison, D.R \& Kanuta, H. (2004), "Blended learning: Uncovering its transformative potential in higher education", The Internet and Higher Education. 7(2), 95-105.

17. Graff, M. (2003, October), "Individual differences in sense of classroom community in a blended learning environment", Journal of Educational Media, 28(2-3), 203-210.

18. Hijazi, S., Crowley, M., Smith, M.L., and Schaffer, C. (2006, "Maximizing learning by teaching blended courses", Proceedings of the 2006 ASCUE Conference, Myrtle Beach, South Carolina. Retrieved February 9, 2010 from http://fits.depauw.edu/ ascue/Proceedings/2006/Papers/p67.pdf.

19. Jenny Leach, Bob Moon, (1999), Learners \& Pedagogy, SAGE, 1999 - Education - 280 pages

20. Kerres, Michael \& De Witt, Claudia (2003), "A didactical framework for the design of blended learning arrangements", Journal of Educational Media. 28 (2-3), 101-113.

21. King, P., \& Hildreth, D. (2001), "Internet courses: Are they worth the effort?", Journal of College Science Teaching, 31, 112-115.

22. Gosper, M., Green, D., McNeill, M,Phillips, R.A., Preston, G., Woo, K., (2008), "Final Report: The Impact of Web-Based Lecture Technologies on Current and Future Practices in 
Learning and Teaching", Australian Learning and Teaching Council, Sydney (2008) <http://mq.edu.au/ltc/altc/wblt/docs/report/ce6-22_final2.pdf >.

23. Gould, T. (2003), "Hybrid classes: Maximizing institutional resources and student learning",

Proceedings of the 2003 ASCUE Conference, Myrtle Beach, South Carolina. Retrieved

February 8, 2015 from http://www.ascue.org/files/proceedings/2003/p54.pdf.

24. MacDonald, J., \& McAteer, E. (2003, October), "New approaches to supporting students: strategies for blended learning in distance and campus based environments", Journal of Educational Media, 28(2-3), 129-146.

25. O'Toole, J.M., \& Absalom, D.J. (2003, October), “The impact of blended learning on student outcomes: is there room on the horse for two?", Journal of Educational Media, 28(2-3), 179190.

26. Parkinson, D., Greene, W., Kim, Y., \& Marioni, J. (2003), "Emerging themes of student satisfaction in a traditional course and a blended distance course", Tech Trends, 47(4), 22-28.

27. Priluck, R. (2004), "Web-assisted courses for business education: An examination of two sections of Principals of Marketing", Journal of Marketing Education, 26(2), 161-173.

28. Reasons, Saxon G., Valadares, Kevin, \& Slavkin, Michael. (2005), "Questioning the hybrid model: Student outcomes in different course formats", Journal of Asynchronous Learning, 9(1), 83-94.

29. Riffell, S.K., \& Sibley, D.F. (2004), "Can hybrid course formats increase attendance in undergraduate environmental science courses?", Journal of Natural Resources and Life Sciences Education, 33, 1-5.

30. Rovai, A.P., \& Jordan, H.M. (2004, August), "Blended learning and sense of community: A comparative analysis with traditional and fully online graduate courses", International Review of Research in Open and Distance Learning, 5(2). Retrieved March 17, 2005 from http://www.irrodl.org/content/v5.2/rovai-jordan.html

31. Saade, R., \& Kira, D., (2009), "Computer Anxiety in E-Learning: The Effect of Computer Self-Efficacy", Journal of Information Technology Education, Vol-8, pp.177-191

32. Schweizer, K., Paechter, M., \& Weidenmann, B. (2003, October), "Blended learning as a strategy to improve collaborative task performance", Journal of Educational Media, 28(2-3), 211-224.

33. Sitter, V., Carter, C., Mahan, R., Massello, C. and Carter, T. (2009), "Hybrid course design: Faculty and student perceptions", Proceedings of the ASCUE 2009, Myrtle Beach, South Carolina. Retrieved on February 8, 2015 from http://www.ascue.org/files/ proceedings/ 2009/p40.pdf.

34. Watkins, C., Mortimore, P., (1999) Pedagogy: what do we know? In: Mortimore P (ed) Understanding Pedagogy and its Impact on Learning. Paul Chapman/Sage, London

\section{Website visited:}

1. http://media.wiley.com/product_data/excerpt/67/07879729/0787972967.pdf

2. $\quad$ Friesen (2012) "Report: Defining Blended Learning"

3. Knewton "Blended Learning: A Disruptive Innovation"

4. "6 Models of Blended Learning". DreamBox. Retrieved on 24-01-2015

5. DeNisco, Alison. "Different Faces of Blended Learning". District Administration. Retrieved on 24-01-2015

6. "The Four Important Models of Blended Learning Teachers Should Know About". Educational Technology and Mobile Learning. Retrieved on 24-01-2015

7. "Blended Learning: How Brick-and-Mortar Schools are Taking Advantage of Online Learning Options". Connections Learning. Retrieved on 24-01-2015

8. $\quad$ "Blended Learning 101". Aspire Public Schools. Retrieved on 24-01-2015

9. "6 Models of Blended Learning". Idaho Digital Learning. Retrieved on 24-01-2015 
10. publications. "For Frustrated Gifted Kids, A World of Online Opportunities". KQED. Retrieved on 24-01-2015

11. http://jite.org/documents/Vol5/v5p235-249Heinze156.pdf

12. http://uupinfo.org/research/working/bradford.pdf 